\title{
YALE NATURAL RADIOCARBON MEASUREMENTS VI
}

\author{
MINZE STUIVER and EDWARD S. DEEVEY
}

Geochronometric Laboratory, Yale University, New Haven, Connecticut

The following list includes most of the measurements made since publication of Yale V; some measurements, such as a series collected in Greenland by A. L. Washburn, are withheld pending additional information or field work that will make better interpretations possible. In addition to radiocarbon dates of geologic and/or archaeologic interest, we give in the third part of the paper, for the first time since 1954 (Deevey and others, 1954), recent assays of $\mathrm{C}^{14}$ in lake waters and other lacustrine materials, now normalized for $\mathrm{C}^{13}$ content. Some of these $\mathrm{C}^{13}$ values have been published separately (Oana and Deevey, 1960), but most have not. We follow the newly accepted convention (Lamont VIII) in expressing normalized $\mathrm{C}^{14}$ values as

$$
\Delta=\delta \mathrm{C}^{14}-\left(2 \delta \mathrm{C}^{13}+50\right)\left(1+\frac{\delta \mathrm{C}^{14}}{1000}\right)
$$

where $\Delta$ is the per mil deviation of the $\mathrm{C}^{14}$ of the sample from any contemporary standard (whether organic or a carbonate) after correction of sample and/or standard for real age, for the Suess effect, for normal isotopic fractionation, and for deviations of $\mathrm{C}^{14}$ content of the age- and pollution-corrected 19th-century wood standard from that of $95 \%$ of the NBS oxalic-acid standard; $\delta \mathrm{C}^{14}$ is the measured deviation from $95 \%$ of the NBS standard, and $\delta \mathrm{C}^{13}$ is the deviation (measured on a Consolidated mass-spectrometer, Model 21-401) from the NBS limestone standard, both in per mil. These assays, made in 1958 and later, are of course variously affected by artificial $\mathrm{C}^{14}$ resulting from nuclear tests, and we withhold detailed or general comments until our studies have continued for at least another season.

Grateful acknowledgment is made to many donors and collectors for assistance in compiling field information, to Yale undergraduates Jonathan King and Sheldon Nankin for limnologic field work, and to Laura Jean Gralenski (until June, 1960), George Young, and Anneke Stuiver for technical assistance in the laboratory. Our work has been generously supported by the National Science Foundation, under grant no. G-7016, and by the U. S. Atomic Energy Commission, under contract AT(30-1) -2652.

\section{SAMPLE DESCRIPTIONS}

\section{GEOLOGIC SAMPLES}

\section{Y-762. Port Hood Island, Nova Scotia}

$10,710 \pm 240$

Populus (id. by W. L. Stern) wood and peat from between two tills, N shore of Port Hood Island (46. $01^{\prime} 17^{\prime \prime} \mathrm{N}$ Lat, $61^{\circ} 33^{\prime} 49^{\prime \prime} \mathrm{W}$ Long), Nova Scotia. Section exposed in ancient sink in gypsum, transected by modern wavecut cliff. It shows $4 \mathrm{ft}$ of modern organic material overlying $7 \mathrm{ft}$ of till. This till is underlain by a lens, $5.5 \mathrm{ft}$ thick, of interbedded organic material and sand, and then by till, of which $20 \mathrm{ft}$ is exposed. Coll. 1959 and subm. by 
Charles F. Hickox, Jr., Colby College, Waterville, Maine. Comment: the sample appears to be of Two Creeks age, as expected. A pollen zone believed to be correlative with the Valders substage was dated at Gillis Lake, Nova Scotia (Y-524, 10,160 \pm 160 , Yale IV).

\section{Y.773. Blue Hill Bay, Maine}

Birch (?) wood from a stump rooted in gray silty clay, now submerged at least $13.5 \mathrm{ft}$ at high tide (as indicated by hand-levelling), E side of Trumpet Island $\left(44^{\circ} 14^{\prime} 07^{\prime \prime} \mathrm{N}\right.$ Lat, $68^{\circ} 26^{\prime} 05^{\prime \prime} \mathrm{W}$ Long), Blue Hill Bay, Maine. Stump is rooted in firm substratum, probably postglacial marine sediment; thus subsidence due to compaction is considered unlikely. Coll. 1959 and subm. by A. L. Bloom, Yale University (now at Cornell University, Ithaca, N. Y.). Comment: similar dates of stumps in similar stratigraphic postions are: W.396, $2980 \pm 180$, Wells, Maine (USGS IV) and W-508, $2810 \pm 200$, Wells, Maine (USGS V). A younger date was given by W.509, $1280 \pm 200$, Kennebunk Beach West, Maine (USGS V), and older dates were given by W-510, $3250 \pm 200$, Kennebunk Beach East, Maine (USGS V), L-118, 4150 \pm 200 , Sagadahoc Bay, Maine (Lamont II), and Y-156, 4190 \pm 200 , Odiorne Point, New Hampshire (Yale IV). Y-773 shows greater submergence than any of the others, and was expected to be older than most of them; as it is not, the possibility of differential land movements along the Maine coast must be considered.

Y-840. Killam's Point, Connecticut

$910 \pm 120$

Cedar root, imbedded in growth position 32 in. below MHW, S end of Killam's Point Marsh ( $41^{\circ} 15^{\prime} \mathrm{N}$ Lat, $72^{\circ} 50^{\prime} \mathrm{W}$ Long), Branford, Connecticut. Inclosing peat contained abundant fragments of stalks and culms of Scirpus, overlain by 4 in. of silty Spartina alterniflora peat and 22 in. of $S$. patens peat. Coll. 1960 and subm. by A. L. Bloom, Yale University (now at Cornell University, Ithaca, N. Y.). Comment: Killam's Point Marsh was the subject of a classic study by Knight (1934). The date, like that of Y-855 (this date list), indicates a recent marine transgression at a rate of about 3.5 in. per century.

\section{Y-855. Guilford Point, Connecticut}

$$
1180 \pm 80
$$

Oak log, imbedded in 14-in. layer of black freshwater peat, 45 in. below surface of tidal marsh (which is at MHW), W edge of Guilford Point $\left(41^{\circ} 16^{\prime}\right.$ N Lat, $72^{\circ} 40^{\prime} \mathrm{W}$ Long), Guilford, Connecticut. Log protruded from face of wave-cut bank of peat; the freshwater layer was overlain by $40 \mathrm{in}$. of gray muddy salt-marsh peat, and underlain by gray-brown medium sand. Coll. 1960 and subm. by A. L. Bloom, Yale University (now at Cornell University, Ithaca, N. Y.). Comment: see Y-840 (this date list) for a similar date showing a comparable rate of submergence at Killam's Point, $8.5 \mathrm{mi} \mathrm{W}$.

Y-843. Stiles Brickyard, Connecticut

$6810 \pm 170$

Log, imbedded in well sorted cross-stratified gray medium sand, overlain by $2 \mathrm{ft}$ of gray medium sand, $3.5 \mathrm{ft}$ of gray silt, and $13 \pm 1 \mathrm{ft}$ of estuarine peat, SE corner of Stiles Brick Co. clay pit $\left(41^{\circ} 22^{\prime} \mathrm{N}\right.$ Lat, $72^{\circ} 53^{\prime} \mathrm{W}$ Long), 
North Haven, Connecticut. Section similar to that described by Brown (in Flint, 1930); the sand, interpreted as alluvium, unconformably overlies laminated New Haven clay. Coll. 1960 and subm. by A. L. Bloom, Yale University (now at Cornell University, Ithaca, N. Y.). Comment: forest trees from this alluvium (id. by Brown) included maple, hemlock, and two species of oak, and now are seen to prove the alluvium to be younger than the late-glacial age assigned it by Flint (1930). The date supports this revised interpretation, but gives only a maximum age for the beginning of marine submergence at this locality.

\section{Y-727. Lloyd Rock Hole, Pennsylvania}

$11,300 \pm 1000$

Charcoal from cave fill, level 83, $15 \mathrm{ft}$ below surface, in Sink No. 4 or Lloyd Rock Hole $\left(40^{\circ} 07^{\prime} \mathrm{N}\right.$ Lat, $78^{\circ} 37^{\prime} \mathrm{W}$ Long), New Paris district, Bedford County, Pennsylvania; alt $1500 \mathrm{ft}$. Associated fauna includes boreal and subarctic mammals, such as Microtus xanthognathus (Leach) (Guilday and Bender, 1960); a complete skeleton of the extinct peccary Mylohyus pennsylvanicus was found at the same level, 14 to $15 \mathrm{ft}$ below surface. Pollen flora from the cave matrix (id. by Paul S. Martin) is also boreal (dominated by small-pollen pine) or subarctic, but pollen flora from rodent droppings is temperate, dominated by oak, probably implying that some rodents burrowed into the deposit after its formation. Coll. 1958 by A. D. McCrady and Ralph Boissart; subm. by J. E. Guilday, Carnegie Museum, Pittsburgh 13, Pennsylvania. Comment: as the locality is 100 to $150 \mathrm{mi}$ outside the limit of $\mathrm{W}$ isconsin drift, a Two Creeks date is not surprising. Bones, mostly snowshoe hare (Lepus americanus), found at a slightly deeper level (17.5 to $21.5 \mathrm{ft}$ ), were dated at $9540 \pm 500$ (M-1067, Michigan VI).

\section{Y-841. Newman's Point, Virginia}

$3160 \pm 160$

Ostrea and Littorina (?) shells from pocket in top $2 \mathrm{ft}$ of clayey fine sand exposed in wave-cut cliff, Newman's Point $\left(36^{\circ} 52^{\prime} 00^{\prime \prime} \mathrm{N}\right.$ Lat, $76^{\circ} 30^{\prime} 30^{\prime \prime} \mathrm{W}$ Long), NE corner of Chuckatuck $71 / 2$ min quadrangle, on Nansemond River, Nansemond County, Virginia. Shells were coll. from 18 in. to 30 in. below surface. They appeared to have been washed into the pocket by natural processes; accumulation by human agency seemed less likely but was not excluded. Coll. 1960 and subm. by R. F. Flint and J. E. Sanders, Yale University. Comment: human agency appears to have been responsible, judging from the young age.

\section{Anaktuvuk Pass series, Alaska}

Wood fragments and organic matter from deposits related to glaciation in the Anaktuvuk Pass district, Alaska. Coll. 1959 and 1960 and subm. by Stephen C. Porter, Yale University.

\section{Y-770. Summit Lake}

$6260 \pm 160$

Wood fragments from perennially frozen lacustrine silt, $9 \mathrm{ft}$ below present ground surface in an Eskimo cellar beside Summit (Eleanor) Lake $\left(68^{\circ} 09^{\prime}\right.$ N Lat, $151^{\circ} 43^{\prime} \mathrm{W}$ Long). Coll. 1959. Comment: inclosing silt was deposited in a small temporary lake marginal to wasting ice during retreat of Echooka 
glaciation. This glaciation was tentatively assigned an early Wisconsin age by Detterman, Bowsher, and Dutro (1958), but evidently should be considered late Wisconsin.

\section{Y-771. Inukpasugruk Creek}

$2830 \pm 120$

Wood fragments from base of $17.5-\mathrm{ft}$ section of stratified gravel on Inukpasugruk Creek, $6.8 \mathrm{mi}$ above its mouth $\left(68^{\circ} 02^{\prime} \mathrm{N}\right.$ Lat, $151^{\circ} 14^{\prime} \mathrm{W}$ Long). The gravel constitutes an outwash fan, which grades upstream into an end moraine that postdates the Echooka glaciation. Coll. 1959. Comment: see Y-873.

Y-772. Anivik Lake

$1170 \pm 120$

Organic matter from layer, $1 \mathrm{in.} \mathrm{thick,} \mathrm{underlying} 15 \mathrm{in}$. of loess, $0.5 \mathrm{mi}$ beyond terminal moraine of Echooka glaciation, near Anivik Lake $\left(68^{\circ} 12^{\prime}\right.$ $\mathrm{N}$ Lat, $151^{\circ} 03^{\prime} \mathbb{W}$ Long). Organic layer overlies stratified sand and pebble gravel. Coll. 1959. Comment: dates the beginning of a period of eolian sedimentation that is younger than the outwash (Y-771, Y-871, Y-872, Y-873), and may be correlative with glacial events recorded by end moraines in cirque valleys near Anaktuvuk Pass.

\section{Y-871. Anaktuvuk River}

Wood from outwash $\mathrm{N}$ of the Echooka end moraine in valley of Anaktuvuk River, $9 \mathrm{mi} \mathrm{N}$ of Anaktuvuk Pass $\left(68^{\circ} 15^{\prime} \mathrm{N}\right.$ Lat, $151^{\circ} 32^{\prime} \mathrm{W}$ Long). Coll. $1.0 \mathrm{ft}$ from bottom of cutbank of river, exposing $8.5 \mathrm{ft}$ of stratified sand, silt, and interbedded organic matter. Coll. 1960.

\section{Y-872. Anaktuvuk River}

$1120 \pm 90$

Wood from outwash $\mathrm{N}$ of Echooka end moraine, $1.5 \mathrm{mi} \mathrm{N}$ of Y-871 $\left(68^{\circ}\right.$ $16^{\prime} \mathrm{N}$ Lat, $151^{\circ} 30^{\prime} \mathrm{W}$ Long), $2 \mathrm{ft}$ from base of cutbank exposing $11 \mathrm{ft}$ of stratified sand, silt, clay, and interbedded organic matter. Coll. 1960.

\section{Y.873. Anaktuvuk River}

$1045 \pm 200$

Wood from outwash $\mathrm{N}$ of Echooka end moraine, $13 \mathrm{mi} \mathrm{N}$ of Anaktuvuk Pass and $4 \mathrm{mi} \mathrm{N}$ of Y-871 $\left(68^{\circ} 18^{\prime} \mathrm{N}\right.$ Lat, $151^{\circ} 29^{\prime} \mathrm{W}$ Long), $2.5 \mathrm{ft}$ from base of cutbank exposing $20.5 \mathrm{ft}$ of stratified sand, silt, clay, and interbedded organic matter. Coll. 1960. Comment: Y.771, younger than the Echooka glaciation and older than the cold period recorded by the loess (Y-772), dates an end moraine believed to be correlative with moraines of the Alapah Mountain glaciation that lie $17 \mathrm{mi} \mathrm{E}$ of Anaktuvuk Pass. These moraines were tentatively assigned a late Wisconsin age by Detterman, Bowsher, and Dutro (1958), but the glaciation dated here was post-Hypsithermal. The other outwash samples, coll. from a continuous body of sediment containing no marked unconformities, also appear to belong to the Alapah Mountain glaciation, and suggest that outwash deposition was continuous throughout the time from 2760 to 1045 B.P.

\section{Lago di Monterosi series, Italy}

Gyttja from cores under ca. $5 \mathrm{~m}$ of water, Lago di Monterosi $\left(42^{\circ} 12^{\prime} \mathrm{N}\right.$ Lat, $12^{\circ} 18^{\prime} \mathrm{E}$ Long), a small explosion crater $\mathrm{N}$ of Rome, believed to have 
been formed during the second or main part of the Würm glacial age. Two cores were coll. in 1959 by Enrico Bonatti and W. T. Edmondson; core M-I has been used mainly for studies of pollen, diatoms, and $\mathrm{C}^{14}$, core M-II for detailed chemistry; enough chemistry has been done on M-I for cross-correlation with M-II. Both cores show a great maximum of organic matter in the middle; above this, sedimentation was very fast, below it, very slow. Subm. by G. E. Hutchinson and Ursula Cowgill, Yale University.

Y-974. Monterosi M-I, 244 to $248 \mathrm{~cm} \quad 24,460 \pm 1300$

Bottom of core M-I. Pollen mainly Artemisia, practically all nonarboreal. Organic C content $15.6 \%$.

Y.913. Monterosi M-I, 128 to $148 \mathrm{~cm} \quad 1573 \pm 77$

Upper part of the zone of maximum organic $\mathrm{N}$, now shown clearly to correspond to Roman settlement. Organic C content $10.3 \%$.

Y-914. Monterosi M-I, 108 to $128 \mathrm{~cm}$

$1349 \pm 75$

Above zone of maximum organic N. Organic C content $5.8 \%$.

Y-915. Monterosi M-I, 73 to $88 \mathrm{~cm}$

$1003 \pm 76$

Organic C content $5.7 \%$.

Y-916. Monterosi M-I, 58 to $73 \mathrm{~cm}$

$984 \pm 72$

Organic C content $5.6 \%$. Comment: the region is believed never to have been inhabited by agricultural man until Roman times, and lake sediments accumulated very slowly. With the coming of the Romans the sedimentation rate was sharply accelerated, and the sediments became much more organic. Use of the land diminished in early medieval times, and more inorganic gyttja was deposited. Throughout the sedimentary record the dominant inorganic material is a noncrystalline clay-like substance, probably to be called allophane.

\section{Lago de Petenxil series, Guatemala}

Gyttja from cores under ca. $4 \mathrm{~m}$ of water, Lago de Petenxil $\left(17^{\circ} 55^{\prime} \mathrm{N}\right.$ Lat, $89^{\circ} 50^{\prime} \mathrm{W}$ Long), the first lake $\mathrm{E}$ of Flores in an $\mathrm{E}-\mathrm{W}$ chain of lakes, Dept. of El Petén, Guatemala. Three cores were coll. in 1959 by George and Ursula Cowgill; none is yet proved to have reached the oldest sediments of the lake. Cores II and III have been subjected to chemical and clay-mineral analysis. Diatoms appear to be absent, and pollen studies are still incomplete. The dominant clay-mineral appears to be halloysite, its degree of hydration yet to be determined. The local bedrock is limestone, but no appreciable inorganic carbon was found in the cores studied. Both cores show series of maxima and minima of exchangeable $K$, but the relation between the two cores is not yet established. Subm. by G. E. Hutchinson and Ursula Cowgill, Yale University.

Y-987. Petenxil III, 85 to $92 \mathrm{~cm}$

$635 \pm 140$

Core III, 85 to $92 \mathrm{~cm}$ depth, at greatest maximum of exchangeable K.

Y-988. Petenxil III, 145 to $149 \mathrm{~cm}$

$1305 \pm 140$ able $\mathrm{K}$.

Core III, 145 to $149 \mathrm{~cm}$ depth, at second-greatest maximum of exchange- 
Y.989. Petenxil III, 181 to $187 \mathrm{~cm}$

$1590 \pm 140$

Core III, 181 to $187 \mathrm{~cm}$ depth, at minimum of exchangeable K.

Y.990. Petenxil III, $225 \mathrm{~cm} \quad 2170 \pm 85$

Bottom of core III, 225 to ca. $229 \mathrm{~cm}$ depth, at a maximum of exchangeable K.

Y-842. Petenxil II, 166 to $221 \mathrm{~cm}$

$2880 \pm 80$

Core II, 166 to $221 \mathrm{~cm}$ depth, sample disturbed during extrusion and therefore larger than desirable; maxima of exchangeable $\mathrm{K}$ occur above and below this sample. Comment: land clearance by burning in this region is known to increase the exchangeable-K content of soil (Cowgill, in press). On the assumption that some of this $\mathrm{K}$, when leached from soils, is delivered to the lake, maxima of exchangeable $\mathrm{K}$ in the sediments record major episodes of burning, and hence of agricultural activity. The inference, from the dates, that some of these episodes are older than about 3000 B.P., is of interest to archaeologists, and warrants further detailed study.

Y-766. Ascension Island

$1200 \pm 120$

Phosphatic dust, unaltered by percolating water, from near bottom of deposit, 18 in. thick, under overhanging rock, ca. $0.5 \mathrm{mi}$ inland, in lava field $\mathrm{S}$ of S Gannet Hill ( $7^{\circ} 57^{\prime} \mathrm{S}$ Lat, $14^{\circ} 21^{\prime} \mathrm{W}$ Long), Ascension Island. The deposit contained fragments of feathers of tropic-birds (Phaethon spp.), two species of which breed elsewhere on the island today, but the large lava field in which the large deposit occurs is now entirely deserted by birds. Coll. 1958 and subm. by Philip Ashmole, Edward Grey Institute, Oxford University, through G. E. Hutchinson, Yale University. Comment: the large breeding-bird colony that produced the deposit probably became extinct some time after the discovery of the island in A.D. 1501, perhaps in the early 19th century when mammalian predators were introduced. The date confirms the impression, given by the lack of alteration in protected places, that even the older part of the deposit is relatively recent.

\section{ARCHAEOLOGIC SAMPLES}

\section{Tazumal series, EI Salvador}

Charcoal from complex I of structure 1, Tazumal ( $13^{\circ} 58^{\prime} 52^{\prime \prime} \mathrm{N}$ Lat, $89^{\circ} 40^{\prime} 35^{\prime \prime}$ W Long), near Chalchuapa, Dept. of Santa Ana, El Salvador. Excavated 1950 to 1955 and subm. 1958 by Stanley H. Boggs, Claypool, Indiana.

Y-682. Tazumal 3

$1480 \pm 120$

Pot 1 , grave 16, structure 1 ; sample 3 .

Y-684. Tazumal 5

Below phase 6 stairs, central structure, $\mathrm{W}$ side; sample 5.

Y.685. Tazumal 6

$1520 \pm 120$

Pot 8 , grave 13 , structure 1 ; sample 6. Comment: no great difference in age was expected among the samples. Their dates confirm belief that archi- 
tectural complex I, pertaining to the main period of construction, was contemporary with classic Maya culture. Certainly sample 5 (Y-684) and prob-

ably sample 6 (Y-685) refer to structural phases of that complex. The report on this site is in preparation.

\section{Matapalo series, Costa Rica}

Charcoal from midden, Matapalo site (10 $22^{\prime} \mathrm{N}$ Lat, $85^{\circ} 49^{\prime} \mathrm{W}$ Long), Guanacaste province, Costa Rica. The site is stratified, with Zoned Bichrome pottery, Monte Fresco phase, underlying polychrome pottery, Matapalo phase, of the Early Polychrome B period. Coll. 1959 and subm. by Michael D. Coe, Yale University.

Y-810. Matapalo, Monte Fresco, 2

$1870 \pm 200$ phase.

Sample no. 2 ( $\mathrm{G} 11 / 2 \mathrm{~J})$, cut 2, 1.35 to $1.50 \mathrm{~m}$ depth; Monte Fresco

Y-809. Matapalo, Monte Fresco, 1

$1530 \pm 280$

Sample no. 1 (G 11/1K), cut $1,1.50$ to $1.65 \mathrm{~m}$ depth; Monte Fresco phase. Comment: because some air may have been admitted during preparation of Y-809, Y-810 is believed to be more reliable as a date for the Zoned Bichrome period. The date of A.D. 90 is reasonable for a pottery phase with marked resemblance to late Formative wares (e.g. Utatlan) elsewhere in Middle America; Utatlan pottery of the Providencia phase at Kaminaljuyu (Y-370, $1850 \pm 60$, Yale IV) is closely similar. The date of Y-809 seems a little late, though not impossibly so.

Y-811. Matapalo phase, 3

$1395 \pm 90$

Sample no. 3 (G 11/1E), cut $1,0.60$ to $0.75 \mathrm{~m}$ depth; Matapalo phase. Comment: this polychrome phase is stratigraphically higher than Y-809 and Y-810, and the date confirms this. The Early Polychrome B period, associated elsewhere in NW Costa Rica with Nicoya jade and carved metates, was equated on stylistic grounds with the end of the Early Classic and the beginning of the Late Classic in the Maya area. The date (A.D. 565) confirms this alignment.

\section{Y-814. Miramar Site, Costa Rica}

$220 \pm 100$

Charcoal from midden, sample no. 6 ( $\mathrm{G} 10 / 3 \mathrm{C})$, cut $3,0.30$ to $0.45 \mathrm{~m}$ depth, Miramar site ( $10^{\circ} 17^{\prime} \mathrm{N}$ Lat, $85^{\circ} 50^{\prime} \mathrm{W}$ Long), Guanacaste province, Costa Rica. The site, on the margin of a mangrove swamp, is apparently of a single phase, but lacks polychrome pottery; it may be coeval with the Matapalo (Early Polychrome) or Tamarindo (Late Polychrome) phases. An alternative explanation is that the extremely thick, crude pottery represents the remains of a Chorotegan salt-making station of Conquest or even post-Conquest age. Coll. and subm. 1959 by Michael D. Coe, Yale University. Comment: although the sample lay close to the surface and may be either contaminated or intrusive, the very late date is not impossible.

Y-815. Huerta del Aguacate Site, Costa Rica

$990 \pm 70$

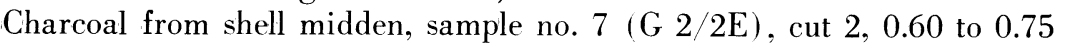
m depth, Huerta del Aguacate site $\left(10^{\circ} 19^{\prime} \mathrm{N}\right.$ Lat, $85^{\circ} 49^{\prime} \mathrm{W}$ Long), Guana- 
caste province, Costa Rica. The only phase represented is Tamarindo, Middle Polychrome period; many of the famous "Nicoya Polychromes" are associated. Coll. and subm. 1959 by Michael D. Coe, Yale University. Comment: confirms stratigraphic evidence from other sites that Middle Polychrome is later than Early Polychrome (e.g. Matapalo phase, Y-811, $1396 \pm 90$, this date list), and confirms chronologic estimates based on external correlations.

Y-816. Chahuite Escondido Site, Costa Rica

$840 \pm 70$

Charcoal from shell midden, sample no. 8 (B 1/1B), cut $1,0.15$ to 0.30 $m$ depth, Chahuite Escondido site $\left(10^{\circ} 55^{\prime} \mathrm{N}\right.$ Lat, $85^{\circ} 43^{\prime} \mathrm{W}$ Long), Guanacaste province, Costa Rica. Associated pottery is of La Cruz phase, Late Polychrome period. This is the final prehistoric culture of the Guanacaste region, associated with Luna Polychrome, and probably dates from the Conquest or shortly before. Coll. and subm. 1959 by Michael D. Coe, Yale University. Comment: in satisfactory agreement with the archaeologic sequence as inferred, though a little older than expected.

\section{Y-850. Ortega Site, Costa Rica}

$1700 \pm 70$

Charcoal from hearth, $1.70 \mathrm{~m}$ depth, Ortega site $\left(10^{\circ} 22^{\prime} \mathrm{N}\right.$ Lat, $85^{\circ} 28^{\prime}$ W Long), Guanacaste province, Costa Rica. Associated pottery is of Catalina phase, Zoned Bichrome period, and should be at least as old as the Monte Fresco phase found at the Matapalo site by Coe, which it is intended to check. Coll. 1960 by C. F. Baudez, Musée de l'Homme, Paris, and subm. by Michael D. Coe, Yale University. Comment: in satisfactory agreement with Y-810, $1870 \pm 200$, Monte Fresco phase, Matapalo site (this date list).

\section{La Mata series, Venezuela}

Charcoal from house, built on Terrace 3 (third-youngest) above Lake Valencia, La Mata ( $10^{\circ} 10^{\prime} \mathrm{N}$ Lat, $67^{\circ} 34^{\prime} \mathrm{W}$ Long), state of Aragua, Venezuela. The site was excavated by Bennett (1937), and re-examined by Cruxent because the associated pottery, of Valencia style, can be assigned to Period IV in the Rouse-Cruxent sequence, and because there has been doubt of the conclusion (Cruxent and Rouse, 1958-59, vol. 1, p. 164-168) that the whole terrace sequence above the lake, known since Humboldt's time, is protohistoric and historic. Coll. 1958 by J. M. Cruxent; subm. by Irving Rouse, Yale University.

\section{Y-630. La Mata 1}

$1000 \pm 70$

Mound 1, level 9, 2.00 to $2.25 \mathrm{~m}$ depth.

Y-631. La Mata 2

$980 \pm 110$

Mound 1, level 6, depth not stated.

Y-632. La Mata 3

$1000 \pm 100$

Mound 1, level 6, depth not stated. Comment: three floors were encountered in the new excavation, but no appreciable age difference between them was expected. The dates are slightly early for Period IV, which is placed at 400 to 800 B.P. As Kidder (1944, p. 36) showed, La Cabrera style antedates all the terraces of Lake Valencia; no date has yet been obtained for it, but El 
Palito style at Aserradero (Y-579, Y-580, mean age A.D. 320, this date list) is comparable, as are other Period II dates in Yale II, Yale III, and Yale IV. The beginning of the terraces is therefore bracketed between about the 4 th and the 10th 'centuries A.D., but their climatic implication, if any, is still obscure.

\section{Aserradero series, Venezuela}

Charcoal from Aserradero site ( $10^{\circ} 28^{\prime} \mathrm{N}$ Lat, $68^{\circ} 07^{\prime} \mathrm{W}$ Long), El Palito, state of Carabobo, Venezuela. Associated pottery is of El Palito style, late Period II and Period III, in the Rouse-Cruxent sequence. Coll. 1957 by students and subm. by J. M. Cruxent, Museo de Ciencias Naturales, Caracas.

\section{Y-579. Aserradero B}

$1640 \pm 120$

Section G-9, 0.25 to $0.50 \mathrm{~m}$ depth.

Y-580. Aserradero C

$1615 \pm 120$

Section and level not stated. Comment: the material appears to be all of one age, falling almost exactly on the boundary between Periods II and III, which is placed at 1600 B.P. (Cruxent and Rouse, 1958-59, p. 9, 83-88).

\section{Nachikufu series, Northern Rhodesia}

Charcoal from various culture levels in Nachikufu cave $\left(12^{\circ} 14^{\prime} \mathrm{S}\right.$ Lat, $31^{\circ} 15^{\prime} \mathrm{E}$ Long), near Mpika, Northern Rhodesia, the type-site of Nachikufan culture, and at the related rock-shelter site of Kasama ( $10^{\circ} 13^{\prime} \mathrm{S}$ Lat, $31^{\circ} 12^{\prime}$ E Long). Excavations at Nachikufu in 1953 by J. Desmond Clark, RhodesLivingstone Museum, Livingstone, Northern Rhodesia, and at Nachikufu and Kasama in 1955 by Mrs. L. Hodges. Subm. 1958 by Clark (now at University of California, Berkeley) through Hallam L. Movius, Harvard University, Cambridge, Massachusetts.

Y-618. Nachikufu Iron Age N 1953 1953 excavation, 0.5 to $1.0 \mathrm{ft}$ depth.

$\mathbf{3 0 0} \pm \mathbf{2 0 0}$

Y-796. Nachikufu Iron Age N 1955

$200 \pm 100$

1955 excavation, 2.0 to $3.0 \mathrm{ft}$ depth.

Y-619. Nachikufu, Nachikufan III

$5000 \pm 200$

1953 excavation, 1.5 to $2.0 \mathrm{ft}$ depth.

Y-619 bis. Nachikufu, Nachikufan III

$4830 \pm 320$

Recheck of Y-619, new preparation.

Y-805. Kasama, Nachikufan III or II

1955 excavation, 2.5 to $3.0 \mathrm{ft}$ depth.

charcoal residue

$7320 \pm 200$

alkali-soluble fraction

Y-791. Nachikufu, Nachikufan II

$5630 \pm 200$

1953 excavation, 2.5 to $3.0 \mathrm{ft}$ depth. Comment: sample very small, not pre-treated with alkali. 
Y.620B. Nachikufu, Nachikufan II

$9720 \pm 550$

1953 excavation, 3.0 to $3.5 \mathrm{ft}$ depth. Comment: a mislabelled sample (Y.620), supposedly from this layer, gave $400 \pm 130$ and has been rejected.

Y.799. Nachikufu, Nachikufan II, N 1955

$1060 \pm 100$

1955 excavation, 5.0 to $7.0 \mathrm{ft}$ depth. Comment: this sample presumably represents contaminating Iron Age material and is also rejected.

Y-625. Kasama, Nachikufan II

$8640 \pm 240$

1955 excavation, 3.0 to $3.5 \mathrm{ft}$ depth.

Y-808. Kasama, Nachikufan II

1955 excavation, 4.5 to $7.0 \mathrm{ft}$ depth.

charcoal residue

$10,820 \pm 340$

alkali-soluble fraction

$11,700 \pm 280$

\section{Y-623-624. Nachikufu, Nachikufan I}

1953 excavation, combined samples, 6.0 to 7.0 and 7.0 to $8.0 \mathrm{ft}$ depth.

charcoal residue

$3460 \pm 200$

alkali-soluble fraction

$7540 \pm 600$

Comment: except for Y.791, all samples were pre-treated with alkali as usual. Samples believed to be bone charcoal (Y-805, Y-808, Y-623-624) were divided during pretreatment, and the alkali-soluble material was dated separately. Normally, as found by the Groningen Laboratory, the alkali-soluble fraction is at least slightly older, and, as the removal of soluble material is not $100 \%$ complete, doubt is thrown on both measurements. This series of dates, though reasonably consistent internally, is in serious conflict with archaeologic evidence at several points. Nachikufan III contains pottery, and iron slag was found down to $1.5 \mathrm{ft}$, immediately overlying Y-619; its 5000-yr date is considered impossibly old. Nachikufan II contains polished stone axes, not known to be older than $6300 \mathrm{yr}$ even in North Africa, whence the Neolithic presumably came, and while Y.791 $(5630 \pm 200)$ is reasonable, it is the least reliable on technical grounds, and the older dates (Y-620B, Y-625, Y-808) are much too old. Nachikufan I was dated at Chifubwa Rock Shelter as $6310 \pm 250$ (C-663, Chicago III), but if the alkali-soluble fraction of Y.623-624 is arbitrarily selected as consistent with this date, all dates for Nachikufan II and III must be rejected. As the gross error of Y-623-624 shows, there is clearly something wrong about bone charcoal, but bone was not a major constituent of most of the samples, and the direct tests do not suggest that error from this source is quantitatively sufficient to account for the discrepancies. Apart from archaeologic difficulties, which can only be resolved by new excavations, sources of error are probably both geochemical (absorption of humic material after burial) and biologic (fractionation of carbon isotopes by food plants, by animals, and by the charring process). 
III. GEOCHEMICAL SAMPLES

\section{A. Linsley Pond, North Branford, Connecticut} ( $41^{\circ} 19^{\prime} \mathrm{N}$ Lat, $72^{\circ} 47^{\prime} \mathrm{W}$ Long)

Yale no.

Description

$\delta \mathrm{C}^{14} / \mathrm{co} \quad \delta \mathrm{C}^{13 \%} \%$ $\Delta \% c$

Y-748. Linsley Nuphar 1958 $+189 \pm 7 \quad-22.0+184 \pm 7$

Nuphar sp. (yellow water-lily) leaves; coll. 19 September 1958 by E. S. Deevey.

\section{Y-750. Linsley Nuphar 1959}

$$
+230 \pm 11-24.4 \quad+229 \pm 11
$$

Nuphar sp. (yellow water-lily) leaves; coll. 21 October 1959 by E. S. Deevey.

\section{Y-892. Linsley Nuphar 1960}

$$
+210 \pm 5 \quad-23.5 \quad+206 \pm 5
$$

Nuphar sp. (yellow water-lily) leaves; coll. 5 October 1960 by E. S. Deevey.

\section{Y-749. Linsley Potamogeton 1958}

Potamogeton sp.; coll. 19 Sep- $+12 \pm 7 \quad \mathbf{2 0 . 6}+\mathbf{3} \pm \mathbf{7}$ tember 1958 by E. S. Deevey.

\section{Y-893. Linsley Potamogeton 1960}

Potamogeton sp.; coll. 5 October $\quad+\mathbf{5 6} \pm 6 \quad-17.6+40 \pm 6$ 1960 by E. S. Deevey.

Y-906. Linsley terrestrial $1960+210 \pm 7-29.5+221 \pm 7$ Sassafras leaves, on Twin Lakes Road on hill above Linsley Pond; coll. 20 October 1960 by E. S. Deevey.

Y-742. Linsley deep water $1958-86 \pm 5-17.2 *-102 \pm 5 *$ Water, $14 \mathrm{~m}$ depth; coll. 20 October 1958 by E. S. Deevey, S. Oana, and S. Horie.

Y-746. Linsley surface water $1959-9 \pm 11-10.6 *-40 \pm 11 *$

Surface water; coll. 29 October 1959 by E. S. Deevey and S. Nankin.

\section{Y-825. Linsley surface water} early $1960 \quad-21 \pm 7 \quad-8.1 * \quad-56 \pm 7 *$

Surface water; coll. 22 March 1960 by E. S. Deevey and K. Elgmork.

$* \delta \mathrm{C}^{13 *}$ determined on aliquot of unpurified $\mathrm{CO}_{2}$ from water sample; purification of the gas for $\mathrm{C}^{14}$ counting enriches the $\mathrm{C}^{13}$ content by an average of $1.2 \%$ (average of 5 samples). The $\Delta$ values for all water samples have been calculated on the assumption of $1.2 \%$ enrichment in $\mathrm{C}^{13}$. 
Yale no.

Description

$\delta \mathrm{C}^{14 \%} \% \quad \delta \mathrm{C}^{13 \%} \%$

$\Delta \%$

Y-908. Linsley deep water late

$$
1960
$$

$$
-36 \pm 7-14.1 * \quad-59 \pm 7 *
$$

Water, $13.5 \mathrm{~m}$ depth; coll. 1 October 1960 by E. S. Deevey and J.

A. King.

Y-909. Linsley surface water late

$$
1960+70 \pm 8-6.8 *+29 \pm 8 *
$$

Surface water; coll. 5 October 1960 by E. S. Deevey and S. Nankin.

$$
\begin{aligned}
& \text { B. Queechy Lake, Canaan, New York } \\
& \left(42^{\circ} 24^{\prime} \mathrm{N} \text { Lat, } 73^{\circ} 25^{\prime} \mathrm{W} \text { Long }\right)
\end{aligned}
$$

\section{Y-899. Queechy Potamogeton}

$$
1958
$$

$$
-131 \pm 6 \quad-17.3 \quad-144 \pm 6
$$

Potamogeton sp.; coll. 29 September 1958 by E. S. Deevey.

Y-754A. Queechy Potamogeton organic 1959

$-125 \pm 8 \quad-12.6 \quad-147 \pm 8$

Potamogeton sp., organic carbon; coll. 12 July 1959 by E. S. Deevey.

\section{Y-754B. Queechy Potamogeton inorganic 1959}

Lime crust deposited on Pota$-101 \pm 10-2.5 \quad-141 \pm 10$ mogeton sp. in summer; coll. 12 July 1959 by E. S. Deevey.

\section{Y-857. Queechy Potamogeton}

$$
1960
$$$$
-118 \pm 7 \quad-15.1 \quad-135 \pm 7
$$

Potamogeton sp.; coll. 5 July 1960 hy E. S. Deevey.

Y-898. Queechy Chara 1958
Chara sp. (calcareous alga); coll. 29 September 1958 by E. S. Deevey.

\section{Y-755. Queechy Chara 1959 \\ Chara sp. (calcareous alga); coll.}

12 July 1959 by E. S. Deevey.

Y-856. Queechy Chara $1960 \quad-137 \pm 6 \quad-19.1 \quad-147 \pm 6$

Chara sp. (calcareous alga); coll.

5 July 1960 by E. S. Deevey.

\section{Y-858. Queechy Nymphaea}

$$
1960
$$$$
+218 \pm 4-23.0+213 \pm 4
$$

Nymphaea sp. (white water-lily) leaves: coll. 5 July 1960 by E. S. Deevey. 
Yale no. Description

$$
\begin{aligned}
& \delta \mathrm{C}^{14} \% \mathrm{C}^{13 \%} \% \\
& 1959-286 \pm 18-11.4^{*}-307 \pm 18 *
\end{aligned}
$$

Y-745. Queechy deep water

Water, $12 \mathrm{~m}$ depth; coll. 27

September 1959 by E. S. and G. B.

Deevey.

Y-744. Queechy surface water

\section{9}

Surface water; coll. 12 July 1959

$$
-275 \pm 9 \quad-5.9 * \quad-304 \pm 9 *
$$

by E. S. Deevey.

\section{Y-907. Queechy deep water}

1960

Water, $12 \mathrm{~m}$ depth; coll. 2 Oc-

$$
-153 \pm 10-13.6 * \quad-174 \pm 10 *
$$

tober 1960 by E. S. Deevey.

\section{Y-910. Queechy surface water 1960}

$$
-121 \pm 7 \quad-9.0 * \quad-151 \pm 7 *
$$

Surface water; coll. 2 October 1960 by E. S. and G. B. Deevey.

\section{Lake Quassapaug, Middlebury, Connecticut $\left(41^{\circ} 32^{\prime} \mathrm{N}\right.$ Lat, $73^{\circ} 09^{\prime} \mathrm{W}$ Long)}

\section{Y-896. Quassapaug Nuphar}

$$
1958+132 \pm 11-22.9+127 \pm 11
$$

Nuphar sp. (yellow water-lily) leaves; coll. 5 October 1958 by E. S.

Deevey.

\section{Y-894. Quassapaug Nuphar 1960}

$$
+225 \pm 6-23.0+220 \pm 6
$$

Nuphar sp. (yellow water-lily) leaves; coll. 12 October 1960 by E. S. Deevey.

\section{Y-897. Quassapaug Myriophyllum

$$
1958 \quad-14 \pm 6 \quad-27.4 \quad-9 \pm 6
$$ \\ Myriophyllum sp.; coll. 5 Oc- \\ tober 1958 by E. S. Deevey.}

\footnotetext{
Y-895. Quassapaug Myriophyllum$$
1960+43 \pm 8 \quad-27.4 \quad+48 \pm 8
$$

Myriophyllum sp.; coll. 12 Oc-

tober 1960 by E. S. Deevey.
} 
Yale no.

Description

$\delta \mathrm{C}^{14 \%} \% \quad \delta \mathrm{C}^{130} \%$

$\Delta \%$

D. Lake Quonnipaug, Guilford, Connecticut $\left(41^{\circ} 24^{\prime} \mathrm{N}\right.$ Lat, $72^{\circ} 42^{\prime} \mathrm{W}$ Long)

Y-900. Quonnipaug Nuphar

$$
1958+138 \pm 6 \quad-25.7 \quad+140 \pm 6
$$

Nuphar sp. (yellow water-lily)

leaves; coll. 12 October 1958 by E. S.

Deevey.

\section{Y-902. Quonnipaug Nuphar}

$$
\begin{aligned}
& 1960 \\
& \text { ar sp. (yellow water-lily) }
\end{aligned}
$$

Nuphar sp. (yellow water-lily)

leaves; coll. 6 November 1960 by E.

S. Deevey.

\section{Y-901. Quonnipaug Potamogeton

$1958 \quad-32 \pm 7 \quad-12.6 \quad-56 \pm 7$

Potamogeton sp.; coll. 12 Oc-

tober 1958 by E. S. Deevey.

\section{Y-903. Quonnipaug Potamogeton $1960+57 \pm 9 \quad-14.4 \quad+35 \pm 9$ \\ Potamogeton sp.; coll. 6 Novem- \\ ber 1960 by E. S. Deevey.}

\section{E. Rogers Lake, Lyme, Connecticut}

( $41^{\circ} 22^{\prime} \mathrm{N}$ Lat, $72^{\circ} 18^{\prime} \mathrm{W}$ Long)

\section{Y-904. Rogers Lobelia 1960}

$$
-15 \pm 14-28.8 \quad-7.5 \pm 14
$$

Lobelia sp.; coll. 20 September

1960 by E. S. Deevey and M. B.

Davis.

\section{Y.905. Rogers Nymphaea 1960}

$$
+213 \pm 6 \quad-22.6 \quad+207 \pm 6
$$

Nymphaea sp. (white water-lily) leaves; coll. 20 September 1960 by

E. S. Deevey and M. B. Davis.

Y-980. Rogers deep water 1960

$$
+20 \pm 15-21.4^{*}+10 \pm 15^{*}
$$

Water, $18.5 \mathrm{~m}$ depth; coll. 20 September 1960 by E. S. Deevey and J. A. King. 
Date lists:

\section{REFERENCES}

$\begin{array}{ll}\text { Chicago III. } & \text { Libby, 1952 } \\ \text { Lamont II. } & \text { Kulp and others, 1952 } \\ \text { Lamont VIII. } & \text { Broecker and Olson, 1961 } \\ \text { Michigan VI. } & \text { Crane and Griffin, 1961 } \\ \text { USGS IV. } & \text { Rubin and Alexander, 1958 } \\ \text { USGS V. } & \text { Rubin and Alexander, 1960 } \\ \text { Yale II. } & \text { Preston, Person, and Deevey, 1955 } \\ \text { Yale III. } & \text { Barendsen, Deevey, and Gralenski, 1957 } \\ \text { Yale IV. } & \text { Deevey, Gralenski, and Hoff ren, 1959 } \\ \text { Yale V. } & \text { Stuiver, Deevey, and Gralenski, 1960 }\end{array}$

Barendsen, G. W., Deevey, E. S., and Gralenski, L. J., 1957, Yale natural radiocarbon measurements III: Science, v. 126, p. 908-919.

Bennett, W. C., 1937, Excavations at La Mata, Maracay, Venezuela: Am. Mus. Nat. History Anthropol. Papers, v. 36, pt. 2.

Broecker, W. S., and Olson, E. A., 1961, Lamont natural radiocarbon measurements VIII: Radiocarbon, v. 3, p. 176-204.

Cowgill, U. M., in press, Soil fertility and the ancient Maya: Connecticut Acad. Arts Sci. Trans., v. 42.

Crane, H. R., and Griffin, J. B., 1961, University of Michigan radiocarbon dates VI: Radiocarbon, v. 3, p. 105-125.

Cruxent, J. M., and Rouse, Irving, 1958-59, An archaeological chronology of Venezuela: Pan-American Union, Soc. Sci. Mon., no. 6, 2 v.

Deevey, E. S., Gralenski, L. J., and Hoffren, Väinö, 1959, Yale natural radiocarbon measurements IV: Am. Jour. Sci. Radioc. Supp., v. 1, p. 144-172.

Deevey, E. S., Gross, M. S., Hutchinson, G. E., and Kraybill, H. L., 1954, The natural C* contents of materials from hard-water lakes: U. S. Natl. Acad. Sci. Proc,, v. 40, p. 285-288.

Detterman, R. L., Bowsher, A. L., and Dutro, J. T., 1958, Glaciation on the Arctic slope of the Brooks Range, northern Alaska: Arctic, v. 11, p. 43-6il.

Flint, R. F., 1930, The glacial geology of Connecticut: Connecticut Geol. Nat. History Survey, Bull. 47, 294 p., 63 pls., map.

Guilday, J. E., and Bender, M. S., 1960, Late Pleistocene records of the yellow-cheeked vole, Microtus xanthognathus (Leach): Carnegie Mus. [Pittsburgh] Annals, v. 35, p. $315-330$.

Kidder, Alfred, II, 1944, Archaeology of northwestern Venezuela: Peabody Mus. Am. Archaeology Ethnology [Harvard Univ.] Pap., v. 26, no. 1.

Knight, J. B., 1934, A salt-marsh study: Am. Jour. Sci., ser. 5, v. 28, p. 161-181.

Kulp, J. L., Tryon, L. E., Eckelman, W. R., and Snell, W. A., 1952, Lamont natural radiocarbon measurements, II: Science, v. 116, p. 409-414.

Libby, W. F., 1952, Chicago radiocarbon dates, III: Science, v. 116, p. 673-681.

Oana, Shinya, and Deevey, E. S., 1960, Carbon 13 in lake waters, and its possible bearing on paleolimnology: Am. Jour. Sci. ,Bradley Vol., v. 258-A, p. 253-272.

Preston, R. S., Person, Elsine, and Deevey, E. S., 1955, Yale natural radiocarbon measurements II: Science, v. 122, p. 954-960.

Rubin, Meyer, and Alexander, Corrinne, 1958, U. S. Geological Survey radiocarbon dates IV : Science, v. 127, p. 1476-1487.

Supp. 1960, U. S. Geological Survey radiocarbon dates V: Am. Jour. Sci. Radioc. tuiver, Minze, Deevey, E. S., and Gralenski, L. J., 1960, Yale natural radiocarbon measurements V: Am. Jour. Sci. Radioc. Supp., v. 2, p. 49-61. 